\title{
A Script-based Analysis of Verbal Humor in the American and Egyptian Stand-up Comedy: \\ A Contrastive Study
}

\section{Al/ Hanan Mansour*}

\section{hananmansour1991@gmail.com}

\section{$\underline{\text { Abstract }}$}

This study explores the phenomenon of verbal humor and its relationship with stand-up comedy shows. In addition, it seeks to discover the basic role of verbal humor and the analysis of comic examples and their composition, as well as their objectivity. This study applies the model of the theory of comic texts; especially the Incongruity theory by Kant (1790) and the Semantic-based script theory of humor by Raskin, (1985), in order to highlight some joke techniques such as repetition, discourse markers, pauses, audience interaction, pantomime and mimics. This study also addresses the differences between American and Egyptian stand-up comedy programs such as Hot and Fluffy (2007) and I'm not Fat I'm Fluffy (2009) by Gabriel Iglesias and the Stand-up Show (2012) by the Egyptian comedian Hamdy ElMerghany. The study explores the cynical role of verbal humor in stand-up comedy. The comparison between Gabriel Iglesias and Hamdy El-Merghany shows that both use

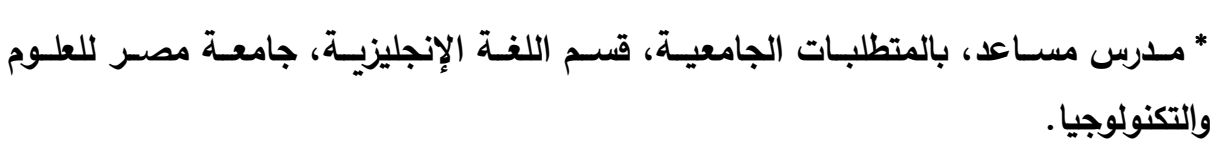


punchlines and joke techniques. However, each of them excels in a particular element rather than the other. Iglesias excels in using joke techniques, while El-Merghany excels in delivering punchlines. Therefore, their performances are totally different.

Keywords: Incongruity Theory - Stand-up Comedy, Punchline - Verbal Humor - Semantic-Based Script Theory of Humor. 


\section{مستخلص}

هناك العديد من الدراسات حول الفكاهة اللفظية أسفرت عن ظهور عدد كبير من النظريات التي تعمل في على تحليل الفكاهة وهياكلها وتفسيرها. تسعى هذه الدراسة لاكتشاف الدور اللغوي الأساسي للفكاهة اللفظية وتحليل بعض الأمثلة الكوميديـة مـن حيث التكوين والموضـوعية. تطبق هذه الدراسـة نموذج نظريـة النصـوص الكوميديـة. وخاصـة نظريـة التتـاقض التـي وضـعها إيمانويـل كانـت

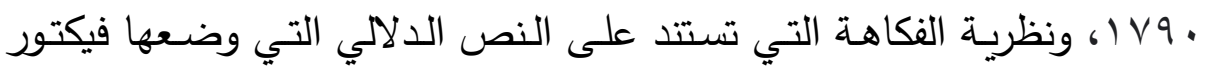
راسـكين 91010، وذلكك لتسـليط الضـوء على بعض الأسـاليب المستخدمة في عرض الفكاهـة اللفظية مثل التكرار ، والتوقف، والتقليد والمحاكاة. تتناول هذه الدراسـة أيضًَ الاختلافـات بـين اثنين مـن مقدمي البرامج الكوميديـة الأمريكيـة

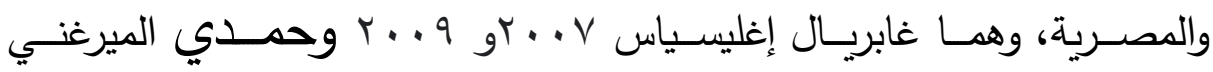
Y Y ب r، وتركز على النقطة الرئيسية في نهاية النكتة التي تثير الضحك. توضح هذه الدراسـة أيضـاً الدور السـاخر للفكاهـة اللفظيـة وتحليـل الأمثلـة الكوميديـة، وهياكلهـا والأدوار الموضـوعات المستخدمة في العـروض الكوميديـة. وتختص بمناقشـة تطبيق نظريـات النصوص الفكاهية، وخاصـة نظريـة التـاقض والنظريـة العامة للفكاهة اللفظية على العروض الكوميدية.

الكلمات المفتاحية: نظرية التناقض - عروض الفكاهة (ستاند آب كوميدي) نهايـة النكتـة التـي تثير الضـكك - الفكاهـة اللفظيـة - نظريـة الفكاهـة التـي تستند على النص الالالي. 


\section{Summary:}

Humor is one of the hallmarks of human behavior; laughter is the physical expression of this behavior. Humor is a social message that aims to produce laughter or smile. Like any other social message humor has various goals such as making people happy, mitigating the tension of situations in different ways. It has its own structure and unique content which are also used in certain situations. Humor has a long history in human culture. Some prominent philosophers such as Plato, Aristotle, Kant, Arthur Schopenhauer, Hobbes, and Bergson have cared about humor and have written articles, books, and theories about it. Likewise, some writers were interested in Humor such as Al-Jahiz, Baudelaire, George Eliot and Umberto Eco. Some psychologists tried to cast light on the psychological dimensions of humor and laughter as well as some literary scholars, including Mikhail Bakhtin. Victor Raskin and Salvatore Attardo introduced The General Theory of Verbal Humor which focuses on the explanation of the contrast between the semantic texts within the framework of humor Semantic-Based Script Theory of humor, which is considered an innovation in the development of the theory of humor.

Strictly speaking, the word humor is originally derived from Latin and refers to the four basic aspects of humor which are language, logic, identity and action. Accordingly, there are two types of comedy, high and low ones. High comedy empolys language and wordplay, while low comedy relies on Bodily motion and visual gags (Berger, 1993, P. 
40). When these Factors are mixed collectively, the character is seen to be immersed in a stable experience of humor, giving a distinct leaning or variation in conduct (Abrams, 1957, P. 101). According to Whitfield (1963, P. 74), this view is consistent with the classical medical theory which states that there are many types of humor such as jokes and stand-up comedies that affect the human mood and produce unique sorts of joy. There is a stable way of life of humor in linguistics and pragmatics. According to the General Theory of Verbal Humor (GTVH) (Attardo, 1994, Attardo and Raskin, 1991, PP. 293-348), humor comes from analyzing the contradiction. It is believed that humor or any other funny text corresponds to two conflicting texts (knowledge structures that provide standard information about routines and activities). A punchline or other elements of the speech leads to a shift in texts and interpretations, leading to humor.

\section{Objectives of the Study:}

This study attempts to discover the methods which can be used by stand-up comedians to elicit laughter and humor. The Incongruity Theory of Verbal Humor suggests that humor happens when we predict an outcome, yet another happens. The punchline (funny ending) results from the fact that there is a distinction between what is actually uttered and what the recipient of the joke received. The researcher will try to validate this point throughout the study. 


\section{Research Questions:}

This research attempts to find adequate answers to the following questions:

1 - To what extent could Iglesias and El-Merghany be analyzed using the set-up and punchline in the Incongruity Theory and the Semantic-based Script Theory of Humor (SSTH)?

2- How do Iglesias and El- Merghany approach their audience?

3 - Which linguistic aspects of joke telling do they follow?

4 - What joke techniques can be found in their stand-up shows?

\section{Data Collection:}

This study focuses on the American and Egyptian stand-up comedy presented by the two comedians Gabriel Iglesias and Hamdy El-Merghany who dealt with a number of everyday social situations in America and Egypt. Iglesias's programs (Hot and Fluffy) 2007 and (I'm not Fat...I'm Fluffy) in 2009 achieved incredible success in America because they tackled real humorous situations, while El-Merghany's program (Stand-up Show) in 2012 resounded success which was the establishment of his prominence. 


\section{Chapterization of the Study:}

\section{Chapter One:}

The researcher began with a general introduction followed by the objectives of the study, research questions and data collection.

\section{Chapter Two:}

The chapter began with an introduction about the verbal humor and its relationship with stand-up comedy shows, in addition to an overview of literature about some humor theories and the history of stand-up comedy.

\section{Chapter Three:}

This chapter introduces the theoretical framework about the Incongruity theory, Semantic-based Script theory, and its extension of the General Theory of verbal humor because they represent the core theories of the study, and the internal structure of jokes, joke techniques, and the use of figurative language in stand-up comedy.

\section{Chapter Four:}

This chapter deals with some joke techniques and the use of figurative language in stand-up comedy. 


\section{Chapter Five:}

This chapter provides a brief bibliography of one of the most influential American stand-up comedian and deals with authentic performances by the comedian Gabriel Iglesias who represents the main data for the analytical part of the study. It provides also a description of Hamdy ElMerghany, an Egyptian actor specialized in performing stand-up comedy and whose performances depend on humans' impersonations which is additionally viewed another primary portion for the analytical part. 


\section{Conclusion:}

There are a lot of contrasts between Gabriel Iglesias and Hamdy El-Merghany in driving punchlines as their styles of overall performance are totally different with their joke techniques and figurative language. Based on the discussions and analysis of some examples of two presenters of verbal humor (stand-up comedy), it is concluded that both Incongruity theory which includes set-up and punchline and Semantic-based Script theory which includes Script Opposition are equal. Therefore, I managed to clarify the application of these two theories on the shows of the two performers - Iglesias and El-Merghany. Although these two theories were developed a long time ago, they are the most popular of all theories at present, still lively and applicable to all contemporary verbal humor content. 